\title{
Seasonal distribution of anti-malarial drug resistance alleles on the island of Sumba, Indonesia
}

Puji BS Asih ${ }^{1}$, William O Rogers ${ }^{2}$, Agustina I Susanti ${ }^{2}$, Agus Rahmat ${ }^{2}$, Ismail E Rozi ${ }^{1}$, Mariska A Kusumaningtyas ${ }^{1}$, Krisin ${ }^{2}$, Sekartuti ${ }^{3}$, Rita M Dewi ${ }^{3}$, Farah N Coutrier ${ }^{1}$, Awalludin Sutamihardja ${ }^{2}$, Andre JAM van der Ven ${ }^{4}$, Robert W Sauerwein ${ }^{5}$ and Din Syafruddin* ${ }^{* 1,6}$

\author{
Address: ${ }^{1}$ Eijkman Institute for Molecular Biology, Diponegoro 69, Jakarta 10430, Indonesia, ${ }^{2}$ Parasitic Diseases Program, Naval Medical Research \\ Unit \#2, Komp. P2P/PLP-LITBANGKES, Jl. Percetakan Negara No. 29, Jakarta Pusat 10560, Indonesia, ${ }^{3}$ Department of Biomedicine and \\ Pharmacology, National Institute for Health Research and Development, Jalan Percetakan Negara 29, Jakarta Pusat, 10560, Indonesia, \\ ${ }^{4}$ Department of Internal Medicine, Radboud University Nijmegen Medical Centre, Nijmegen, The Netherlands, ${ }^{5}$ Department of Medical \\ Microbiology, Radboud University Nijmegen Medical Centre, Nijmegen, The Netherlands and ${ }^{6}$ Department of Parasitology, Faculty of Medicine, \\ Hasanuddin University, Makasar, Indonesia \\ Email: Puji BS Asih - puji@eijkman.go.id; William O Rogers - rogerswo@namrutwo.org; Agustina I Susanti - ika@namrutwo.org; \\ Agus Rahmat - ratmat@namrutwo.org; Ismail E Rozi - eko@eijkman.go.id; Mariska A Kusumaningtyas - acid@yahoo.com; \\ Krisin - krisin@namrutwo.org; Sekartuti - sekartuti@litbang.depkes.go.id; Rita M Dewi - marleta@litbang.depkes.go.id; \\ Farah N Coutrier - farah@eijkman.go.id; Awalludin Sutamihardja - awal@namrutwo.org; Andre JAM van der Ven - A.vanderVen@AIG.umcn.nl; \\ Robert W Sauerwein - R.Sauerwein@mmb.umcn.nl; Din Syafruddin* - din@eijkman.go.id \\ * Corresponding author
}

Published: 29 September 2009

Malaria Journal 2009, 8:222 doi:I0.1 I86/I475-2875-8-222
Received: 18 June 2009

Accepted: 29 September 2009

This article is available from: http://www.malariajournal.com/content/8/I/222

(c) 2009 Asih et al; licensee BioMed Central Ltd.

This is an Open Access article distributed under the terms of the Creative Commons Attribution License (http://creativecommons.org/licenses/by/2.0), which permits unrestricted use, distribution, and reproduction in any medium, provided the original work is properly cited.

\begin{abstract}
Background: Drug resistant malaria poses an increasing public health problem in Indonesia, especially eastern Indonesia, where malaria is highly endemic. Widespread chloroquine (CQ) resistance and increasing sulphadoxine-pyrimethamine (SP) resistance prompted Indonesia to adopt artemisinin-based combination therapy (ACT) as first-line therapy in 2004. To help develop a suitable malaria control programme in the district of West Sumba, the seasonal distribution of alleles known to be associated with resistance to $\mathrm{CQ}$ and SP among Plasmodium falciparum isolates from the region was investigated.

Methods: Plasmodium falciparum isolates were collected during malariometric surveys in the wet and dry seasons in 2007 using two-stage cluster sampling. Analysis of pfcrt, pfmdrl, pfmdrl gene copy number, dhfr, and dhps genes were done using protocols described previously.

Results and Discussion: The 76T allele of the pfort gene is nearing fixation in this population. Pfmdrl mutant alleles occurred in $72.8 \%$ and $53.3 \%$, predominantly as 1042D and $86 \mathrm{Y}$ alleles that are mutually exclusive. The prevalence of amplified pfmdrl was found $41.9 \%$ and $42.8 \%$ of isolates in the wet and dry seasons, respectively. The frequency of $d h f r$ mutant alleles was much lower, either as a single $108 \mathrm{~N}$ mutation or paired with $59 \mathrm{R}$. The $437 \mathrm{G}$ allele was the only mutant dhps allele detected and it was only found during dry season.

Conclusion: The findings demonstrate a slighly higher distribution of drug-resistant alleles during the wet season and support the policy of replacing CQ with ACT in this area, but suggest that SP might still be effective either alone or in combination with other anti-malarials.
\end{abstract}




\section{Background}

The most widely used anti-malarial drugs, chloroquine (CQ) and sulfadoxine-pyrimethamine (SP), are failing at an accelerating rate in most endemic countries, including Indonesia. In response to this situation the World Health Organization has recommended artemisinin-based combination therapy (ACT), wherein an artemisinin derivative is paired with a second partner anti-malarial drug. This policy, however, has several limitations in resourcepoor settings where diagnostic facilities are challenged by availability, cost, compliance and requirements for proper monitoring [1]. In addition, the rapid spread of resistance to currently available anti-malarials is limiting options for ACT partner drugs.

The molecular mechanisms underlying resistance to antimalarial drugs have been investigated. Several single nucleotide polymorphisms (SNPs) in a number of Plasmodium falciparum genes have been associated with resistance to CQ [2] and SP [3]. In addition, amplification of the Plasmodium falciparum multi-drug resistance 1 ( $p f m d r 1$ ) gene has been associated with mefloquine resistance [4].

In Indonesia $\mathrm{CQ}, \mathrm{SP}$ and primaquine have been the most widely used anti-malarial drugs. The drugs are readily available but diagnostic facilities are poor, and as a result their use is often inappropriate, leading to the increased spread of resistance. Resistance to CQ was first reported in 1975, resistance to SP appeared in 1978, and by 1997 treatment failures associated with both drugs had been documented in most provinces $[5,6]$. Molecular epidemiology studies conducted from 2003 to 2005 in several sentinel sites throughout the Indonesia archipelago indicated widespread distribution of mutant alleles associated with resistance to CQ resistance ( $p f m d r 1$ 86Y, Plasmodium falciparum chloroquine resistance ( $p f c r t) 76 \mathrm{~T}$ ) and SP (dihydrofolate reductase (dhfr) and dihydropteroate synthase (dhps)) [7-10]. The mutant allele associated with chloroquine resistance, $p f c r t 76 \mathrm{~T}$, seems to be nearly fixed among the $P$. falciparum isolates collected, and pfmdr1 1042D alleles were mainly found in the island of Flores [9].

Previous studies of the distribution of drug resistance markers in Indonesia were not based on large-scale systematic sampling. In order to study the distribution of drug resistance markers more systematically, samples from a previously reported district wide study of seasonal malaria prevalence in West Sumba was analyzed [11]. The frequency distributions of the alleles across the villages throughout the district of West Sumba is reported.

\section{Methods}

\section{Study site and sampling strategy}

Sumba is a member of the Lesser Sunda Archipelago, located in the province of East Nusa Tenggara, Indonesia, at longitude 118.9 - 119.9 East and latitude $9.3-9.8$ South, with total population of approximately 387,000 in 2007. The study design and sampling strategy have been described elsewhere [11]. Briefly, malariometric surveys were conducted twice, in March 2007 (wet season) and in August 2007 (dry season) using two-stage cluster sampling. The wet season usually occur during November to April whereas the dry season proceeds from May to October. Forty-five clusters (sub-villages) were chosen by probability proportional to size sampling. Within each subvillages, households were chosen randomly by spinning a pointer, and were included until 100 subjects per cluster had been enrolled. Although the same 45 clusters were used in both surveys, no attempt was made to re-sample the same households; instead a new random selection of households was made within each cluster. The malaria prevalence in West Sumba was seasonal with the parasite rates was $6.83 \%$ and $4.95 \%$ in the wet and dry season, respectively. The malaria infections were mostly asymptomatic, mainly occurred among children and teenagers, and the geometric mean parasitemia decreased with age [11].

\section{Data collection}

In each subject, blood was collected by finger or heel prick for thick and thin films on glass slides and for blood blots on filter paper (Whatman, Schleicher \& Schuell, Whatman International Ltd, Maidstone, UK) for malaria diagnosis and parasite genotyping. The study was approved by Eijkman Institute for Molecular Biology Research Ethics Commission, scientific and ethical review boards of the Naval Medical Research Unit \#2, and by the Indonesian National Institute of Health Research and Development.

\section{Genomic DNA preparation}

DNA was extracted from P. falciparum positive blood samples diagnosed by microscopy as well as $10 \%$ of the malaria negative subjects, using chelex-100 ion exchanger (SIGMA, St Louis, USA) according to a procedure described previously [12]. DNA was either used immediately for a polymerase chain reaction (PCR) or stored at $20^{\circ} \mathrm{C}$ for later analysis.

\section{PCR amplification and genotyping of pfcrt, pfmdr I, dhfr, and dhps codons}

Detection of the single nucleotide polymorphisms of $p f c r t$, $p f m d r 1, d h f r$, and $d h p s$ genes was performed using PCR and restriction fragment length polymorphyms (RFLP) as described elsewhere $[3,8,9,13,14]$.

\section{Pfmdrl copy number}

Pfmdr1 copy number was assessed using a Real Time PCR method $[4,15,16]$. The primers and a FAM-TAMRA (6-carboxyfluorescein 6-carboxy-tetra-methylrhodamine) probe specific to a conserved region of $p f m d r 1$ and the 
primers and a VIC-TAMRA (chemical structure not released by Applied Biosystems) probe specific to $\beta$-tubulin were multiplexed so that both genes could be assayed in the same well. PCR reactions were performed on IQ5 Biorad $^{\circledR}$ and consisted of pfmdr1 probe $(150 \mathrm{nmol} / \mathrm{L})$, pfmdr1 primers $(300 \mathrm{nmol} / \mathrm{L}), \beta$-tubulin probe $(100 \mathrm{nmol} /$ L), $\beta$-tubulin primers (100 nmol/L), IQ Multiplex Powermix $(1 \times)$, DNA $(2-4 \mu \mathrm{L})$, and water up to $25 \mu \mathrm{L}$. The cycling conditions were: $95^{\circ} \mathrm{C}$ for 15 minutes for pre denaturation, and 50 cycles of $95^{\circ} \mathrm{C}$ for 15 seconds and $60^{\circ} \mathrm{C}$ for 1 minute. The cycle threshold (CT) was calculated with Optical System Biorad software ver. 1.0. DNA from strains 3D7 and W2mef were included on each plate. Pfmdr1 copy number was calculated according to the following formula: copy number $=\left(\mathrm{E}_{\beta \text { tubulin }}\right)^{\mathrm{CT}(\beta \text { tubulin }) /}$ $\left(\mathrm{E}_{p f m d r 1}\right)^{\mathrm{CT}(p f m d r 1)}$. The efficiency (E) of $\beta$-tubulin, which was higher than that of $p f m d r 1$, was assumed to be 2. Pfmdr1's efficiency, relative to that of $\beta$-tubulin, was calculated for each plate by assuming the 3D7 control has one pfmdr1 copy. The additional control, W2mef, was previously determined to have three pfmdr1 copies [17].

\section{Results}

Distribution of pfort and pfmdr I gene polymorphisms PCR yielded 213 and 231 amplicons in 29 and 32 villages in the wet and dry season, respectively. The pfcrt 76T allele was found in $92.9 \%$ of the $P$. falciparum isolates during the wet season and $84.9 \%$ during the dry season (Table 1). Analysis of isolates for the pfmdr1 gene revealed the existence of mutually exclusive $86 \mathrm{Y}$ and 1042D mutant alleles. The proportion of isolates carrying the $86 \mathrm{Y}$ allele was $41.9 \%$ in the wet season and $42.8 \%$ in the dry season and for the $1042 \mathrm{D}$ allele in the proportion were $72.8 \%$ and $53.3 \%$. The pfmdr 1 mutant alleles $1034 \mathrm{C}$ and $1246 \mathrm{Y}$ were not found in any of the isolates examined. Allelic combinations of $76 \mathrm{~T}$ ( $p f c r t$ ) with $86 \mathrm{Y}(p f m d r 1)$ were found in $23.6 \%$ of the isolates during the wet season and $24.7 \%$ in the dry season whereas combinations of 76T ( $p f c r t)$ with 1042D (pfmdr1) were found in $6.2 \%$ and $5.5 \%$ in the wet and dry seasons, respectively (Table 2 ).

\section{Distribution of pfmdr I copy number}

Analysis of the $p f m d r 1$ gene copy number revealed $10.1 \%$ and $25.9 \%$ of the P. falciparum isolates in the wet and dry seasons, respectively, harbored more than one copy (Table 1). Of which, $72.2 \%$ in the wet and $85.7 \%$ dry seasons had more than one pfmdr1 gene copy number combined with the wild type $86 \mathrm{~N}$ allele. The proportion of isolates that carried more than one copy number of pfmdr1 gene combined with $1042 \mathrm{D}$ was $27.8 \%$ in the wet and $14.3 \%$ in dry season, respectively. The distribution of $P$. falciparum isolates that carried more than one copy number is shown in Figure 1 in each village. The village that has $P$. falciparum isolates with the highest $p f m d r 1$ gene copy number is Lamboya Dete.

\section{Distribution of dhfr and dhps mutant alleles}

Amplification of the $d h f r$ gene showed that $31.5 \%$ of the isolates carried the $108 \mathrm{~N}$ allele in the wet season whereas in dry season the proportion dropped to $24.7 \%$ (Figure 2 ). The $108 \mathrm{~T}$ allele was not detected in any of the isolates examined. The 59R allele was found in $25.6 \%$ and $25.4 \%$ of the P. falciparum isolates in wet and dry seasons respectively, and in most cases was paired with the $108 \mathrm{~N}$ allele. The other $d h f r$ mutant alleles $16 \mathrm{~V}, 50 \mathrm{I}, 51 \mathrm{I}$ and $164 \mathrm{~L}$ were not found in any of the isolates examined. Amplification of the dhps gene revealed no mutant alleles in any of the isolates examined during the wet season whereas in the dry season, the $437 \mathrm{G}$ was found in $2.2 \%$ of the isolates. The other dhps mutant alleles (436A, 540E, 581G and $613 \mathrm{~S} / \mathrm{T}$ ) were not detected in any of the isolates examined.

\section{Distribution of parasite haplotypes by village}

The pattern of the parasite haplotype found in the wet and dry season is shown in Table 3. The P. falciparum isolates that carried wildtype alleles of the $p f c r t, p f m d r 1, d h f r$ and dhps genes, simultaneously were only found in two subjects during dry season in two remote villages of Hoha Wungo (Kodi sub-district) and Lamboya Dete (Lamboya sub-district). On the contrary, due to the very low distribution of mutant alleles of dhps gene, we only found two

Table I: Prevalence of pfcrt, pfmdrl genes and pfmdrl copy number among the isolates of $P$. falciparum in West Sumba District in dry and wet seasons

\begin{tabular}{|c|c|c|c|}
\hline \multirow[t]{2}{*}{ Gene } & \multirow[t]{2}{*}{ Allele } & \multicolumn{2}{|c|}{ Prevalence (\%) } \\
\hline & & Wet Season & Dry Season \\
\hline Pfcrt & $76 \mathrm{~T}$ & $92.9\left(198 / 213^{*}\right)$ & $84.9(147 / 174)$ \\
\hline Pfmdrl copy number > 1.5 & - & $10.1(18 / 178)$ & $25.9(14 / 54)$ \\
\hline \multirow[t]{4}{*}{ Pfmdrl } & $86 Y$ & $41.9(55 /|3|)$ & $42.8(27 / 63)$ \\
\hline & $1034 C$ & $0(0 / 191)$ & $0(0 / 191)$ \\
\hline & I042D & $72.8(139 / 191)$ & $53.3(96 / 180)$ \\
\hline & $1246 Y$ & $0(0 / 191)$ & $0(0 / 191)$ \\
\hline
\end{tabular}

\footnotetext{
* Number in bracket indicates samples examined
} 
Table 2: Prevalence of allelic combinations associated with CQ and SP resistance among isolates of $P$. falciparum in West Sumba District in dry and wet seasons

\begin{tabular}{|c|c|c|c|}
\hline & \multirow[t]{2}{*}{ Allelic Combination } & \multicolumn{2}{|c|}{ Prevalence (\%) } \\
\hline & & Wet Season & Dry Season \\
\hline \multirow{2}{*}{ CQ Resistance } & $76 T+86 Y$ & $23.6\left(4 I / I 74^{*}\right)$ & $24.7(24 / 174)$ \\
\hline & $76 T+1042 D$ & $6.2(11 / 178)$ & $5.5(3 / 54)$ \\
\hline \multirow[t]{2}{*}{ SP Resistance } & $108 N / T+5 I I+59 R$ & 0 (99) & $0(73)$ \\
\hline & $437 G+540 E$ & $0(92)$ & $0(92)$ \\
\hline
\end{tabular}

* Number in bracket indicates samples examined

isolates that carried simoultaneous mutant alleles in the four gene during the dry season.

\section{Discussion}

Molecular analysis of the P. falciparum isolates collected throughout the district of West Sumba indicated that the
76T allele of the pfcrt gene, a molecular marker for CQ resistance, has almost gone to fixation in the local population. Furthermore, nearly half of isolates also simultaneously carried pfmdr1 mutant alleles, either as $86 \mathrm{Y}$ or 1042D (Figure 2). Five mutant alleles of the $p f m d r 1$ gene have been implicated in CQ resistance: $86 \mathrm{Y}, 184 \mathrm{~F}, 1032 \mathrm{C}$,

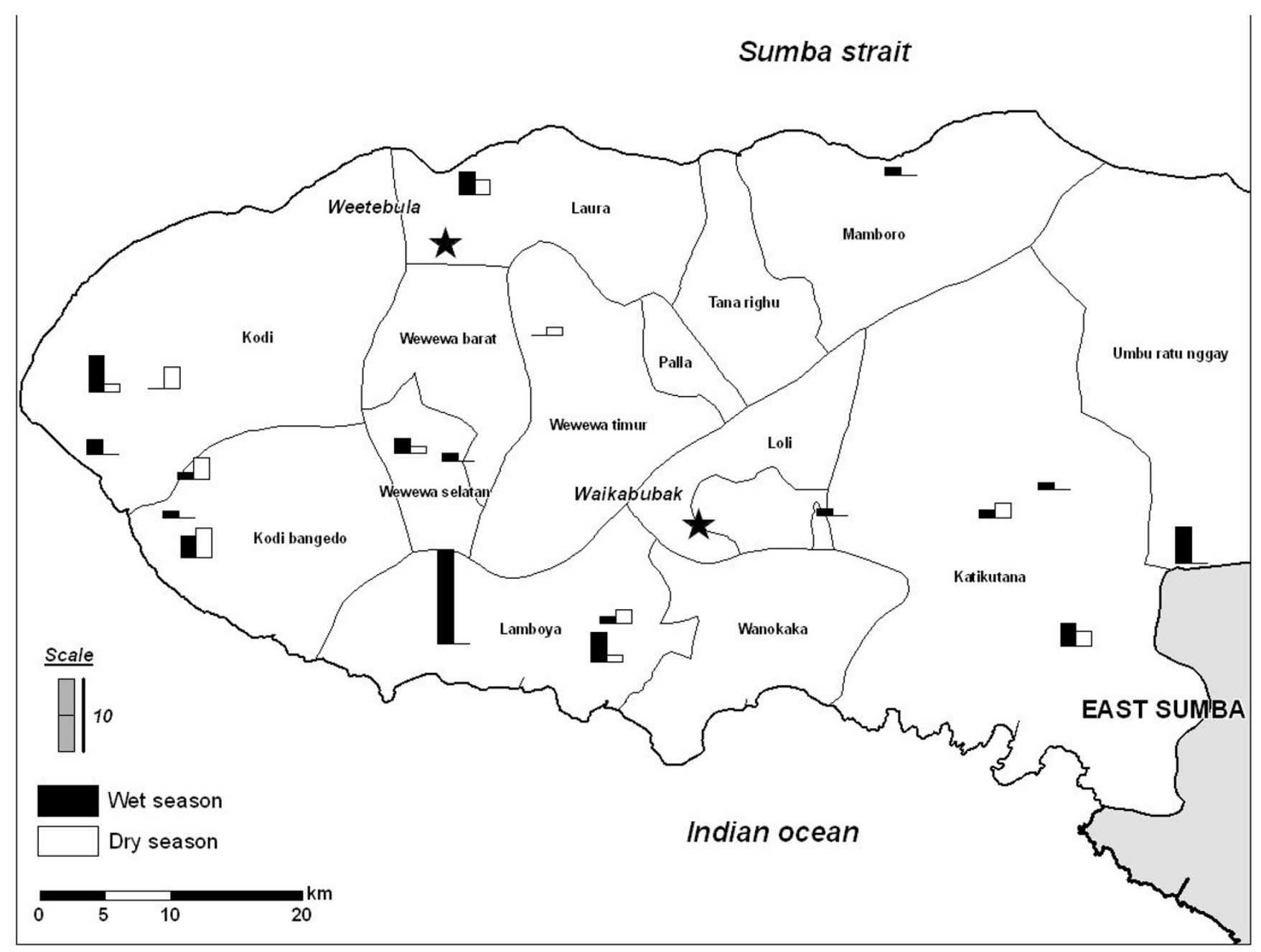

Figure I

Distribution of pfmdrl gene copy number in the wet and dry seasons in West Sumba District. 


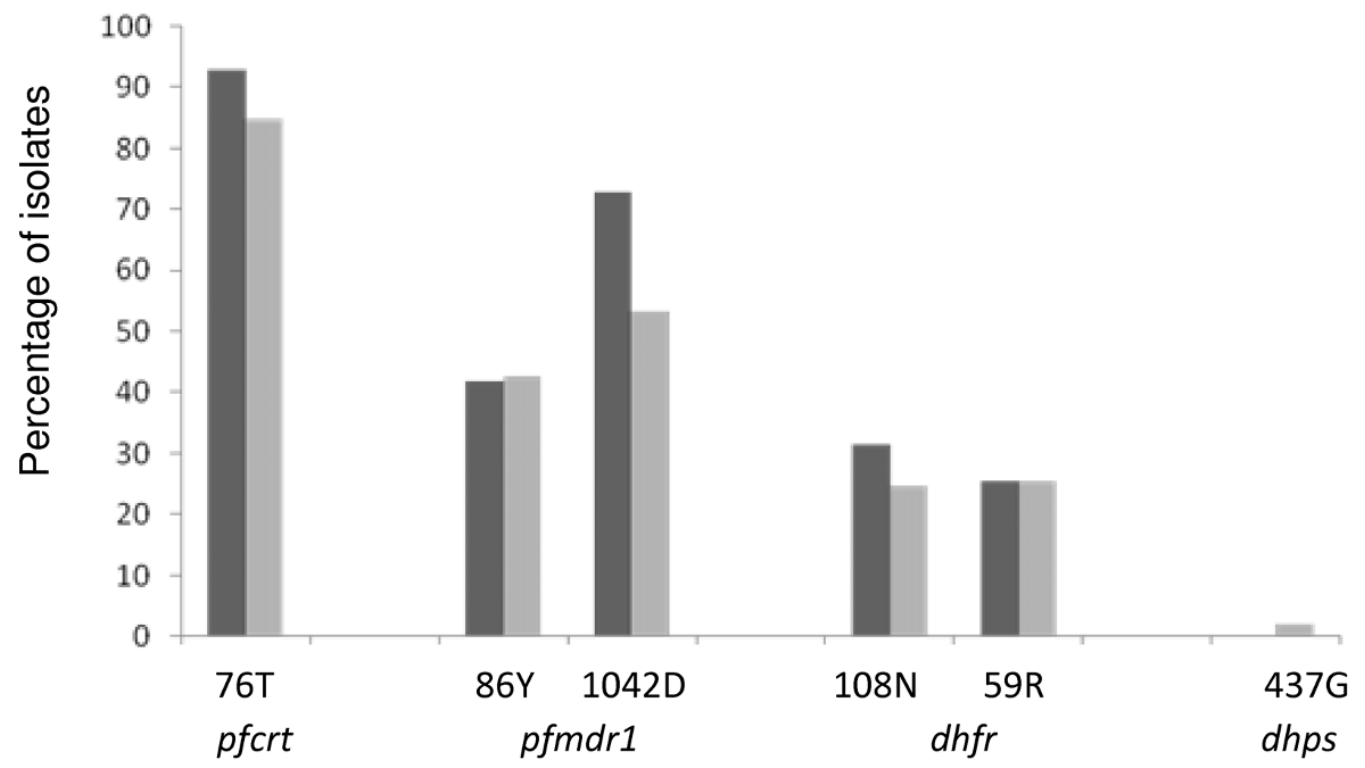

Wet season Dry season

Figure 2

Distribution of anti-malarial drug-resistant alleles in the wet and dry seasons in West Sumba District. The 437G is the only mutant allele of the dhps gene found in this study and it was found in dry season.

$1042 \mathrm{D}$ and $1246 \mathrm{Y}$. Of these, $86 \mathrm{Y}$ and $1042 \mathrm{D}$ are commonly found throughout Asia and Oceania whereas the $1032 \mathrm{C}$ and $1246 \mathrm{~N}$ alleles are typical in $P$. falciparum isolates of Latin American origin [18,19]. In Indonesia, the $86 \mathrm{Y}$ allele is more prevalent in western provinces whereas the $1042 \mathrm{D}$ allele dominates in the east. Interestingly, these alleles were found to be mutually exclusive [9]. These findings endorse abandonment of CQ as the firstline treatment of uncomplicated $P$. falciparum in the district of West Sumba.

Previous data in Africa suggest an associaton between amodiaquine (AQ) treatment failure and parasite isolates carrying a combination of $p f c r t 76 \mathrm{~T}$ and $p f m d r 186 \mathrm{Y}$ alleles $[19,20]$. In this study $P$. falciparum isolates frequently carried the allelic combination of pfcrt 76T and pfmdr1 86Y, but previous study showed artesunate (AS) and AQ combination therapy to be highly effective [10]. This finding suggests that the parasite haplotype 76T and pfmdr1 86N is still sensitive to AQ treatment, particularly in combination with AS. Otherwise, the high efficacy of AQ might be associated with the absence of $1246 \mathrm{Y}$ allele of the pfmdr1 in any of the isolates examined. Previous studies found out the selection of $p f m d r 11246 \mathrm{Y}$ alleles following AQ treatment [21-23].
In the present study, the distribution of the Pfcrt 76T, pfmdr1 86Y, dhfr 108N and dhfr 59R alleles were slightly higher in the wet season (Figure 2). It may be suggested that this overrepresentation of the drug-resistant alleles may reflect relatively higher drug pressure during in the wet season. This suggestion is supported by the fact that the wild type P. falciparum isolates that is found during the dry season.

Analysis of the pfmdr1 gene copy number revealed over $10 \%$ and $25 \%$ of the P. falciparum isolates harbor more than one copy in wet and dry season, respectively. This finding is similar to results in Thailand where the increase in the pfmdr1 gene copy number was associated with resistance to mefloquine and lumefantrine [4]. This finding may indicate that mefloquine and lumefantrine, which are currently used as partner drugs for artesunate and arthemeter, may not be suitable for use in Sumba. Previous studies also reported that increased in copy number of the $p f m d r 1$ gene is more often usually paired with wildtype $86 \mathrm{~N}$ allele in comparison to the mutant $86 \mathrm{Y}[4,19]$. This phenomenon is also observed in this study where the 1042D was the most common pfmdr1 allele found. The increase in pfmdr1 copy number was more often found along with either $86 \mathrm{~N}$ or $1042 \mathrm{~N}$ in comparison to $86 \mathrm{Y}$ of $1042 \mathrm{D}$. The findings indicate that 
Table 3: Genotypic patterns of $P$. falciparum isolates in pfmdrl, pfcrt, dhfr, and dhps genes in the wet and dry seasons

\begin{tabular}{|c|c|c|c|}
\hline \multirow[t]{2}{*}{ Type } & \multirow[t]{2}{*}{ Genotypic Pattern* } & \multicolumn{2}{|c|}{ Frequency (isolates) } \\
\hline & & Wet Season & Dry Season \\
\hline $\mathrm{I}$. & NNKAKASC (wild type) & - & 2 \\
\hline 2. & $\mathrm{NN}(\mathrm{K} / \mathrm{T}) \mathrm{AKASC}$ & I & - \\
\hline 3. & N(N/D)TAKASC & 11 & 25 \\
\hline 4. & $(\mathrm{~N} / \mathrm{Y})(\mathrm{N} / \mathrm{D}) \mathrm{TAKASC}$ & 3 & 12 \\
\hline 5. & NNTAKANR & 2 & 2 \\
\hline 6. & $\mathrm{~N}(\mathrm{~N} / \mathrm{D}) \mathrm{TAKASR}$ & 2 & - \\
\hline 7. & $\mathrm{Y}(\mathrm{N} / \mathrm{D})(\mathrm{K} / \mathrm{T}) \mathrm{AKA}(\mathrm{S} / \mathrm{N}) \mathrm{R}$ & I & - \\
\hline 8. & YNTAKASC & 19 & 6 \\
\hline 9. & YNTAKA(S/N)R & 2 & - \\
\hline 10. & Y(N/D)TAKASC & 15 & 1 \\
\hline II. & NDTAKASC & 17 & 19 \\
\hline 12. & $(\mathrm{~N} / \mathrm{Y}) \mathrm{NTAKANR}$ & 2 & - \\
\hline 13. & $(N / Y)(N / D) K A K A S C$ & 5 & - \\
\hline 14. & $(\mathrm{~N} / \mathrm{Y})(\mathrm{N} / \mathrm{D}) \mathrm{TAKA}(\mathrm{S} / \mathrm{N}) \mathrm{R}$ & 3 & - \\
\hline 15. & $\mathrm{~N}(\mathrm{~N} / \mathrm{D})(\mathrm{K} / \mathrm{T}) \mathrm{AKASC}$ & I & - \\
\hline 16. & NNTAKA(S/N)R & I & - \\
\hline 17. & YNTAKANR & 3 & - \\
\hline 18. & NDTAKANR & 2 & 5 \\
\hline 19. & NNKAKANR & 4 & 8 \\
\hline 20. & NNTAKASC & 10 & 22 \\
\hline 21. & YNTGKASC & - & 2 \\
\hline 22. & Y(N/D)TAKASC & 4 & 1 \\
\hline 23. & $-D(K / T) A K A(S / N) C$ & 1 & - \\
\hline 24. & -DTAKASC & 14 & 21 \\
\hline 25. & -NTAKANR & 2 & 3 \\
\hline 26. & -NKAKASC & 3 & - \\
\hline 27. & -DKAKASC & 2 & 4 \\
\hline 28. & -NTAKASC & 2 & 5 \\
\hline 29. & $-(N / D) T A K A(S / N) C$ & I & - \\
\hline 30. & $-(N / D) T A K A S C$ & 10 & 24 \\
\hline 31. & -(N/D)KAKASC & 1 & 1 \\
\hline 32. & -DTAKA(S/N)C & 2 & 2 \\
\hline 3. & $(N / Y)(N / D) T A K---$ & 5 & 2 \\
\hline 34. & $(N / Y)(N / D) K A K---$ & 5 & 2 \\
\hline 35. & $(N / Y)(N / D) T A K--$ & 8 & 2 \\
\hline 36. & NDTAK--- & 7 & 2 \\
\hline 37. & NNTAK--- & 8 & 3 \\
\hline 38. & YNT---- & 6 & 2 \\
\hline 39. & YNK----- & 1 & 1 \\
\hline 40. & -(N/D)TAK--- & I & 2 \\
\hline 41. & -DTAK--- & 5 & 3 \\
\hline 42. & $-(N / D)(K / T)----$ & 1 & 3 \\
\hline 43. & N-AK--- & 2 & 2 \\
\hline 44. & ND------ & 10 & 22 \\
\hline \multirow[t]{2}{*}{45.} & --T----- & 8 & 20 \\
\hline & Total & 213 & 231 \\
\hline
\end{tabular}

$\left.*\right|^{\text {st }}$ letter $=$ N86Y and $2^{\text {nd }}$ letter $=$ N I042D for pfmdr $l$ gene, $3^{\text {rd }}$ letter $=\mathrm{K} 76 \mathrm{~T}$ for $p f c r t$ gene, $4^{\text {th }}$ letter $=\mathrm{A} 437 \mathrm{G}$ and $5^{\text {th }}$ letter $=\mathrm{K} 540 \mathrm{E}$ for dhps gene, $6^{\text {th }}$ letter $=A 16 \mathrm{~V}, 7^{\text {th }}$ letter $=\mathrm{SI} 08 \mathrm{~N} / \mathrm{T}$ and $8^{\text {th }}$ letter $=$ C59R for dhfr gene. Letters in parentheses indicate mixed allelic infection. -- indicates unsuccessful amplification. under CQ pressure the parasite may undertake either the $p f m d r 1$ gene amplification or mutations, and that the former usually takes place earlier as indicated in the previous study [24].

The proportion of isolates carrying mutant alleles of the $d h f r$ and $d h p s$ gene are relatively small in comparison to the $P$. falciparum isolates collected from the other parts of Indonesia [7-9]. For the dhfr gene, the majority of isolates carried the double mutation $108 \mathrm{~N}+59 \mathrm{R}$, whereas for $d h p s$ only two isolates carried the $437 \mathrm{G}$ allele. It follows that the use of SP as an interim alternative option to AS-AQ could be considered in this area, as the majority of the $P$. falciparum isolates are likely still sensitive to the drug. Treatment failure with SP in Africa is associated with the presence of quintuple mutations in $d h f r$ and $d h p s$ genes, respectively [25].

This study shows that the determining mutant allele associated with CQ resistance is nearly fixed in the parasite population found in the district of West Sumba. A high prevalence of $p f m d r 1$ mutant alleles was also found, reinforcing that CQ should no longer be used in this area. Except for the mutant dhps $437 \mathrm{G}$ allele which was only detected in two subjects during dry season, the distribution of the other drug-resistant alleles is slightly higher in the wet season. In addition, the increasing number of $P$. falciparum isolates carrying more than one copy number of $p f m d r 1$ limit candidate partner drugs for artemisinin as this mutation is associated with resistance to mefloquine and lumefantrine, two of the compounds that are currently used in ACT. However, the relatively low prevalence of mutant alleles in the $d h f r$ and $d h p s$ genes is encouraging for future ACT formulations in this area.

\section{Competing interests}

The authors declare that they have no competing interests.

\section{Authors' contributions}

PBSA, WOR, AIS, AR, EIR, MAK and DS performed field samples collection, molecular assays, data analysis, and the manuscripts writing. $\mathrm{K}, \mathrm{ST}$, RMD, FNC, and AS collected field samples and performed data analysis. AJAM and RWS contributed to data analysis, and the manuscript writing. DS, WOR, AJAM and RWS design the study and were responsible for management and fund raising for this study. All authors read and approved the manuscript.

\section{Acknowledgements}

The authors are grateful for the support of the Eijkman Institute, the National Institute of Health Research and Development of Indonesia and USNAMRU-2, Jakarta. The authors wish to thank Michael Kinzer, lqbal RF Elyazar, Suradi, Suprianto, Sunardi, Faisal Amir of US NAMRU-2, Jakarta, the health professional staff of West Sumba District, and Riyanti Ekowatiningsih of the National Institute of Health Research and Development of Indonesia, Jakarta, for their assistance during the malariometric surveys, 
Rodiah Nababan of the Eijkman Institute, Jakarta, for her assistance in the malaria laboratory, and the Scientific Writing Course Jakarta, South East Asia Infectious Disease Clinical Research Network for their assistance in manuscript preparation. The opinions expressed are the private opinions of the authors and do not purport to represent those of the U.S. Navy. This study was supported by the U.S. Department of Defence Global Epidemic Information System, a grant-in-aid from the Netherlands Foundation for the advancement of Tropical Research through PRIOR programme, and the publication cost from South East Asia Infectious Diseases Clinical Research Network (SEAICRN).

\section{References}

I. WHO: Assessment and monitoring of antimalarial drug efficacy for the treatment of uncomplicated falciparum malaria. (WHO/HTM/RBM/200350) World Health Organization, Geneva; 2003.

2. Djimde A, Doumbo OK, Cortese JF, Kayentao K, Diourte Y, Doumbo S, Dicko A, Su XZ, Nomura T, Fidock DA, Wellems TE, Plowe CV, Coulibaly D: A molecular marker fore chloroquine-resistant falciparum malaria. N Engl J Med 200I, 344:257-263.

3. Duraisingh MT, Curtis J, Warhurst DC: Plasmodium falciparum: detection of polymorphisms in the dihydrofolate reductase and dihydropteroate synthetase genes by PCR and restriction digestion. Exp Parasitol 1998, 89: I-8.

4. Price RN, Uhlemann AC, Brockman A, McGready R, Ashley E, Phaipun L, Patel R, Laing K, Looareesuwan S, White NJ, Nosten F, Krishna S: Mefloquine resistance in Plasmodium falciparum and increased pfmdr I gene copy number. Lancet 2004, 364:438-447.

5. Ebisawa I, Fukuyama T: Choroquine-resistant falciparum malaria from west Irian and East Kalimantan. Ann Trop Med Parasitol 1975, 69:275-282.

6. Tjitra E, Gunawan S, Laihad F, Sulaksono S, Arjono S, Richie TL, Manurung $\mathrm{N}$ : [Evaluation of antimalarial drugs in Indonesia $198 \mathrm{I}$ 1995]. Buletin Penelitian Kesehatan (in Indonesian) 1997, 25:27-58.

7. Syafruddin D, Asih PB, Siregar JE, Tjitra E: Molecular basis of antimalarial drug resistance in Indonesia. Adv Exp Med Biol 2003, 53I:103-II5.

8. Syafruddin D, Asih PBS, Aggarwal SL, Shankar AH: Frequency distribution of antimalarial drug resistant alleles among the isolates of Plasmodium falciparum in Purworejo District, Central Java Province. Am J Trop Med Hyg 2003, 33:325-330.

9. Syafruddin D, Asih PBS, Casey GJ, Maguire J, Baird JK, Nagesha HS, Cowman AF, Reeder JC: Molecular epidemiology of Plasmodium falciparum resistance to antimalarial drugs in Indonesia. Am J Trop Med Hyg 2005, 73:174-181.

10. Asih PBS, Dewi RM, Tuti S, Sadikin M, Sumarto W, Sinaga B, Ven AJAM van der, Sauerwein , Syafruddin D: Efficacy of artemisininbased combination therapy for treatment of persons with uncomplicated Plasmodium falciparum malaria in West Sumba District, East Nusa Tenggara Province, Indonesia, and genotypic profiles of parasites. Am J Trop Med Hyg 2009, 80:914-918.

II. Syafruddin D, Krisin, Asih P, Sekartuti, Dewi RM, Coutrier FN, Rozi IS, Susanti AI, Elyazar IR, Sutamiharja A, Rahmat A, Kinzer M, Rogers WO: Seasonal prevalence of malaria in West Sumba district, Indonesia. Malar J 2009, 8:8.

12. Wooden J, Kyes S, Sibley CH: PCR and strain identification in Plasmodium falciparum. Parasitol Today 1993, 9:303-305.

13. Wellems TE, Plowe CV: Chloroquine-Resistant malaria. J Infect Dis 200I, I 84:770-776.

14. Foote SJ, Kyle DE, Martin RK, Oduola AM, Forsyth K, Kemp DJ, Cowman AF: Several alleles of the multidrug-resistance gene are closely linked to chloroquine resistance in Plasmodium falciparum. Nature 1990, 345:255-258.

15. Reeder JC, Rieckmann KH, Genton B, Lorry K, Wines B, Cowman AF: Point mutations in the dihydrofolate reductase and dihydropteroate synthase genes and in vitro susceptibility to pyrimethamine and cycloguanil of Plasmodium falciparum isolates from Papua New Guinea. Am J Trop Med Hyg 1996, 55:209-213.

16. Ferreira ID, Rosario VE, Cravo PV: Real-time quantitative PCR with SYBR Green I detection for estimating copy numbers of nine drug resistance candidate genes in Plasmodium falciparum. Malar J 2006, 5:I.

17. Dokomajilar C, Nsobya SL, Greenhouse B, Rosenthal PJ, Dorsey G: Selection of Plasmodium falciparum pfmdrl Alleles following therapy with artemether-lumefantrine in an area of Uganda where malaria is highly endemic. Antimicrob Agents Chemother 2006, 50: 1893-1895.

18. Rogers WO, Sem R, Tero T, Chim P, Lim P, Muth S, Socheat D, Ariey $F$, Wongsrichanalai $C$ : Failure of artesunate-mefloquine combination therapy for uncomplicated Plasmodium falciparum malaria in southern Cambodia. Malar J 2009, 8: 10.

19. Babiker HA, Pringle SJ, Abdel-Muchsin A, Mackinnon M, Hunt P, Walliker D: High-level chloroquine resistance in Sudanese isolates of Plasmodium falciparum is associated with mutations in the chloroquine resistance transporter gene, pfcrt and the multidrug resistance gene pfmdrl. I Infect Dis 200I, 183:1535-1538.

20. Holmgren G, Gil JP, Ferreira PM, Veiga MI, Obonyo CO, Bjorkman A: Amodiaquine resistant Plasmodium falciparum malaria in vivo is associated with selection of pfort 76T and pfmdrl 86Y. Infect Genet Evol 2006, 6:309-3 I4.

21. Holmgren G, Hamrin J, Svard J, Martesson A, Gil JP, Bjorkman A: Selection of pfmdrl mutations after amodiaquine monotheraphy and amodiaquine plus artemisinin combination therapy in East Africa. Infect Genet Evol 2007, 5:562-569.

22. Humphreys GS, Merinopoulos, Ahmed J, Whitty CJM, Mutabingwa TK, Sutherlands CJ, Hallett RL: Amodiaquine and ArtemetherLumefantrine Select Distict Alleles of the Plasmodium falciparum mdrl Gene in Tanzanian Children Treated for Uncomplicated Malaria. Antimicrob Agents Chemother 2007, 51:991-997.

23. Ochong EO, Broek IV van den, Keus K, Nzila A: Short report: association between chloroquine and amodiaquine resistance and allelic variation in the Plasmodium falciparum multiple drug resistance I gene and the chloroquine resistance transporter gene in isolates from the upper Nile in southern Sudan. Am J Trop Med Hyg 2003, 69:184-187.

24. Nair S, Nash D, Sudimack D, Nosten F, Anderson T: Characterization of segmental amplification of chromosome 5 associated with multidrug resistance in Plasmodium falciparum. $\mathrm{Am} J$ Trop Med Hyg 2005, 93:1 97.

25. Bwijo B, Kaneko A, Takechi M, Zungu IL, Moriyama Y, Lum JK, Tsukahara T, Mita T, Takahashi N, Bergqvist Y, Bjorkman A, Kobayakawa T: High Prevalence of quintuple mutant dhps/dhfr genes in Plasmodium falciparum infections seven years after introduction of sulfadoxine and pyrimethamine as first line treatment in Malawi. Acta Trop 2003, 85:363-373.

Publish with BioMed Central and every scientist can read your work free of charge

"BioMed Central will be the most significant development for disseminating the results of biomedical research in our lifetime. "

Sir Paul Nurse, Cancer Research UK

Your research papers will be:

- available free of charge to the entire biomedical community

- peer reviewed and published immediately upon acceptance

- cited in PubMed and archived on PubMed Central

- yours - you keep the copyright
BiolMedcentral 